\title{
Pastoral Care in Homes for the Elderly: Selected Issues ${ }^{1}$
}

\section{Věra Suchomelová}

"For everything there is a season and a time for every matter under heaven..." (Eccl 3:18). Old age and especially so-called fourth age poses fundamental tasks and challenges for coping with which "the right time" is precisely at the climax of the life path. It is time (high and last) to solve the unsolved, heal the wounded, finish what has been begun, set right what has gone wrong, open what has been closed, complete and valorize life. ${ }^{2}$ Old age thus gives to its bearer the chance to valorize and fulfil life, but at the same time accumulates life losses and problems in many areas. Metaphorically speaking, old age is a time of reaping the fruit of one's life, some of which may be barely edible. Also for this reason John Paul II calls old age one "of the most difficult chapters of the great art of living". ${ }^{3}$ In this light, pastoral care of the elderly appears not only necessary, but vitally important.

The probably most frequently cited sentence of the preface of the encyclical Gaudium et spes appeals to all Christians concerning the necessity of interest in the joys and the hopes, the griefs and the anxieties of all the men of this age, not only in "Church ground". Pastoral care of the elderly can thus be characterized as accompanying an older person (not only a faithful or even a traditionally religious Christian) in seeking the direction of his life, life balancing in own spiritual development as well as in preparation for death, as assistance to humanly dignified coping with demanding life moments and crises; all that with respect to the uniqueness of the given person including the uniqueness of his spirituality and in any milieu. ${ }^{4} \mathrm{P}$. Ambros speak of pastoral charisma as of an "art of accompanying man in the history of his life and faith". ${ }^{5}$ The milieu of the life of many older persons, especially those with limited self-sufficiency, are homes for the elderly. The specificities of institutionalized living are without doubt projected in the history of life and faith and may intensify some of the difficulties linked to old age. We can therefore ask how the milieu of a residential establishment is projected onto the manner of pastoral care and building up the relationship between the pastoral worker ${ }^{6}$ and the recipient of pastoral care.

The following text is based on partial conclusions of the qualitative study Spiritual Needs in the Life of Elderly Persons in South Bobemia, ${ }^{7}$ realised as part of the author's dissertation thesis. ${ }^{8}$

\footnotetext{
1 This study was realized as part of the project of specific research GAJU 117/2013/H - Conception of quality of social work in connection to self-definition of the social worker and his helping profession.

2 Cf. Aleš OPATRNÝ, Pastorace zuláštních skupin, Červený Kostelec: Pavel Mervart, 2014, p. 34.

3 JAN PAVEL II., Nebojme se pravdy: nedostatky lidí a provinění církve, Praha: Zvon, 1997, p. 73.

4 Cf. the broader definition of pastoral acting in Aleš OPATRNÝ, Pastorace zuláštních skupin, p. 16.

5 Cf. Pavel AMBROS, Fundamentální pastorální teologie, Olomouc: Univerzita Palackého, 2002, p. 117.

6 In a certain sense the pastoral worker can be any Christian close to the elderly person, depending on his human and spiritual maturity. In case of deeper questions, injuries in the spiritual sphere or generally questions of difficulties in the spiritual sphere, the intervention of a "spiritually competent" person with appropriate education is necessary. In Czech reality this means especially a cleric of a particular church or a pastoral assistant.

7 The fundamental data of the research were in-depth interviews with twenty persons seventy-five years of age and older, supplemented by terrain notes from direct observation of the physical environment and social climate in two residential establishments (mentioned under the fictitious names Zálesí and Jiř́kov). Data was collected from January 2012 till June 2013. Communication partners were persons seventy-five years of age and older, half of them living in a home for the elderly. Thematic analysis of data was based on literal transcription.

8 Věra SUCHOMELOVÁ, Senioři a spiritualita: duchovnípotřeby v každodenním životě, České Budějovice, 2015, dissertation thesis, University of South Bohemia, Faculty of Theology, Department of Pedagogy.
} 
The goal is to reflect contemporary practice in the sphere of pastoral care in homes for the elderly and, based on analysis of qualitative data and with respect to the above mentioned conception of pastoral care of the elderly, to formulate some recommendations for pastoral practice (not only) in homes for the elderly.

\section{Pastoral care in homes for the elderly: reflection of contemporary practice}

Czech homes for the elderly can be - with some overstatement - regarded as a mission ground. Spiritual care in these residential establishments is not (unlike e.g. the German speaking neighbouring countries) conceptualized at all. On the one hand it is thus dependent on the good will of the management and current financial possibilities of the given establishment, on the other hand on the possibilities and willingness of churches to take part in this care. If the given establishment ${ }^{9}$ advertises some form of spiritual care, what is mostly meant is certain "service" for those elderly persons who present themselves as Christian faithful and show interest in religious practices..$^{10} \mathrm{~A}$ part of the life of the given establishment is e.g. celebrating the Eucharist or worship of a non-Catholic church once a month, once a week visits by acolytes bringing Eucharist to those who ask for it, or mediated visits of a cleric on demand by a particular person. In this situation the church rather reacts to "demand" and is pastorally active especially with traditionally religious Christians, who are even in the residential establishment in contact with fellow parishioners (or possibly pastor) of their original place of residence, actively show interest in participating in the sacraments, draw strength from spiritual texts and the like. ${ }^{11}$ Schlemmer describes this attitude as pointless aiming of pastoral care especially within own church as part of some sort of self-preserving maintenance process. ${ }^{12}$

Analysis of qualitative data has shown the limits of pastoral care thus conceived. Although a cleric and a pastoral assistant came to both establishments where the research was conducted, none of the interviewed mentioned them as partners for spiritual conversation and had not sought them out for this purpose. Not even persons presenting themselves as faithful mentioned these "spiritual professionals" as someone with whom it would be possible to share life difficulties, solve questions bearing on existential topics or simply establish a closer relationship (unlike nurses, activation workers and friends). One of the causes may be the fact that pastoral workers were perceived especially as carriers of a certain "uninfringible" role. The male pastoral assistant was mainly "the one who brings the Eucharist", the female pastoral assistant "the one who leads the Rosary", and the priest "the one who celebrates mass". This surmise may be supported by an extract from a conversation of the author (S) with Mrs. Marie (M, 85 years old), a faithful, still active, but very lonely woman from the home in Zálesí.

\footnotetext{
9 In this part of the text the author relies not only on terrain observation in the homes Zálesí and Jiř́kov, but especially on information obtained by means of informal questioning of workers in homes for the elderly as part of further education courses, conferences etc.

10 The narrowed conception of spiritual care reflects the common view of spiritual needs on the part of not only the lay public, but often even the professional public and the local church.

11 Cf. Aleš OPATRNÝ, Pastorace zulástních skupin, p. 20.

12 Cf. Karl SCHLEMMER, Českobudějovické teze k pastoraci budoucnosti, in: Pronikavá změna pastorace nebo sebezáchovný provoz? Být církví misionář́sým হpioisobem: mezinárodní pastorálnè teologické sympozium, eds. Zdeněk DEMEL - Karl SCHLEMMER, České Budějovice: Teologická fakulta Jihočeské univerzity, 2005, p. 139.
} 
S: "And there (note: after the regular Wednesday non-Eucharistic worship) you can talk, perbaps when you go to see bim, or if you wanted to discuss something that bothered you perbaps, or you bad something in your head, so you can talk it over with that $\mathrm{Mr} P$. (pastoral assistant)?"

M: "No, he just comes, goes around, he bas about two grannies there whom be brings the Eucharist ”

S: "So be rather just comes and brings the Eucharist."

M: "Just brings the Eucharist, yes, not other things."

S: "And that Mrs. P. (pastoral assistant, wife of Mr P.), just to talk to her, that is also not?" M: "No, she just comes for the Rosary."

Mrs. Marie has never thought (or has not dared to think?) that she may or should confide in one of them with the difficulties and questions arising from her old age, loneliness, insecurity, disappointment. It is thus debatable whether religious elderly persons really have someone to turn to when they feel the (frequently implicit) need for a spiritual conversation or accompanying, unless they are e.g. visited by the priest from their home parish. An even greater void, as far as spiritual assistance and accompanying is concerned, surrounds those elderly persons who present themselves as not faithful or atheists or feel some sort of blockage in relationship to the Church. With respect to the mentioned establishments one can assume that pastoral workers would be humanly as well as expertly capable and willing to accompany the elderly persons in their situation - if they were addressed...

We can summarize that Czech elderly persons living the final phase of their life in a common residential establishment have quality health care and many leisure and therapeutic activities, but often remain helpless and lonely in the most important spheres of their life.

\section{Pastoral care of the elderly as (first of all) a relationship}

Pastoral care of the elderly means first of all relationship and communication, just as faith or spirituality does. The central issues of this relationship are reflected by many post-Vatican II church documents, especially those linked to the person of John Paul II, ${ }^{13}$ but also e.g. the Concluding Document of the Plenary Assembly of the Catholic Church in CR. ${ }^{14}$ For the accompanying person (pastoral worker) this relationship means not only to give - i.e., to understand, respect, help and support, discover the spiritual dimension in anxieties, tasks and challenges -, but also to allow oneself be gifted with the personality and life story of the accompanied person..$^{15}$ A relationship established on such bases provides secure space not only for sharing everyday anxieties and joys, but also for deepest questions, which contemporary elderly persons raise just as the biblical old men did: "What is the meaning of pain, evil, death? What are those victories, so dearly reached, for? What comes after this earthly world?" 16 Based on the conclusions of the survey and the analytical part of the

13 Cf. e.g. the document PAPEŽSKÁ RADA PRO LAIKY, Duistojnost seniora a jeho poslání v církvi a ve světě, Praha: Česká biskupská konference, 2010; or JAN PAVEL II., List starým lidem, Praha: Česká biskupská konference, 1999.

14 Cf. Život a poslání krestanu v církvi a ve svètè, Final document of the Plenary Assembly of the Catholic Church in CR, Kostelní Vydř́: Karmelitánské nakladatelství, 2007.

15 More on the topic see Aleš OPATRNÝ, Pastorace zuláštních skupin; or also Vladimír BOUBLÍK, Teologická antropologie: cloveek $v$ Kristu Ježišisi, Kostelní Vydři: Karmelitánské nakladatelství, 2006, p. 80.

16 Cf. Dokumenty II. vatikánskébo koncilu, Kostelní Vydří: Karmelitánské nakladatelství, 2002. Constitution Gaudium et spes, art. 10. Further only GS and section number. 
qualitative study Spiritual Needs in the Life of Elderly Persons in South Bohemia and with reference to the above definition of pastoral care it has been possible to characterize several aspects of pastoral care of older persons (not only) in homes for the elderly.

\section{Own initiative in establishing contact}

As has already been said, none of the participants in the research, whether religious or nonreligious, living in a home for the elderly or in their own apartment, mentioned a cleric or a pastoral assistant as persons in whom they could confide with their questions or anxieties and to whom they could talk of their difficulties.

This fact may be caused by a certain diffidence in the presence of "church authority" and at the same time a vague idea of the competencies of the priest of pastoral assistant. Elderly persons religiously socialized in pre-Vatican II church usually were not and are not used to establishing friendly, confidential relationships with the clergy (which is not quite so exceptional among contemporary young and middle aged persons).

Analysis of data has also partly uncovered the reason why many elderly persons, though Christian, need not even meet the cleric who comes to the home for the elderly. Its conclusions have confirmed the preference for private living out of religiosity in higher age to the detriment of participation in church community declared by other authors, ${ }^{17}$ also in the case of traditionally religious elderly persons. For many of them personal spirituality or faith means especially internal space where they are alone with God, their near ones, their ideals and desires that transcend them. The preference for living religiosity out in private can have several causes. First, it may be a natural tendency to quiet and contemplation in own interior in the sense of Tornstam's gerotranscendence, which characterizes old age as transcendent in itself, typical for which is obliteration of borderlines between past, present and future, decrease of interest in the material and in superficial relationships, and on the other hand increased need for lonely contemplation. ${ }^{18}$ Second, it may be a need for internal space as refuge from the threatening or humiliating environment, a private place in which human dignity is not attacked, where man meets God and his near ones, where he can be himself, where love is not wounded, where there is still space for faith and hope. Third, a part may be played by past injuries linked to church practice and subsequent loss of trust in the Church as institution, fourth, it may be the simple aversion to staying in the company of people one does not like and must nonetheless meet daily or even share a room with them. Last but not least, the cause may be more or less "technical" reasons preventing the older person from participating fully in the community: unsuitable space (e.g. a dining room with uncomfortable chairs) or insufficient respect of the pastoral worker to sensory or cognitive limitations giving rise to communication barriers. An example may be the following extract from interview with Mrs. Stela (79) from the home in Jiř́kov, a faithful woman with many physical difficulties. Stela first motivated her negative attitude to participating in the church community in the home by a general distrust of the clergy, but immediately afterwards

17 Cf. Walter FÜRST et al., „Selbst die Senioren sind nicht mebr die alten... “Praktisch-theologische Beiträge zu einer Kultur des Alterns, Münster: Lit Verlag, 2003.

18 Cf. Lars TORNSTAM, Gerotranscendence - a theory about maturing into old age, Journal of Aging and Identity 1/1996, pp. 37-50. 
mentioned quite practical reasons - sensory limitations: "We have a chapel here, the pastor comes here once a week or two weeks. I can't hear what he says. I can't see well...(...) So it wasn't much good. So I say, why should I sit there, just looking like this."

We can summarize that just as God comes to meet man, ${ }^{19}$ so pastoral workers must themselves go out to meet persons in need, in a manner they are able to understand and accept. A certain "detection" of the needy and making first contact with them must undoubtedly come from the initiative of the pastoral worker, which is certainly easier in a home for the elderly than in case of lonely persons living in their own apartments.

\section{Love of the neighbour as point of departure}

The conclusions of the study did not indicate significant differences in the intensity and experiencing of spiritual needs between inhabitants of residential establishments and elderly persons living in their own environment, with one exception: inhabitants of homes for the elderly experienced the need for love much more intensively, both in the sense of receiving love and in the sense of giving love, being useful.

In a milieu that often attacks human dignity (especially in case of involuntarily shared rooms), the older person all the more needs to feel accepted, respected, needs to feel as one who has something to give and can still be useful. He needs to know that he is loved, needs to experience God's love. A mature Christian attitude of the pastoral worker makes it possible to "endow him with a loving look, which he needs so much". ${ }^{20}$ Benedict XVI recalls the close link between love of God and love of neighbour. ${ }^{21}$ Pastoral care in this sense means "be with the person", not link the care and interest to reaching a certain goal, respect his uniqueness including his unique and original relationship to God and level of his faith. Pastoral care thus conceived gives the old person value, dignity, helps him preserve hope and faith. The already mentioned first sentence of the preface of constitution Gaudium et spes refers to empathy, respect and love as the essence of any pastoral activity: "nothing genuinely human fails to raise an echo in the hearts of the followers of Christ." 22

Meeting another person can even in old age set off a decisive step on the path to spiritual maturity. ${ }^{23}$ Unconditional love and respect for the neighbour anchored in love of God can be regarded as "pivotal channels" of pastoral care of the elderly.

\section{Openness}

Loving spiritual intervention helps any elderly person (i.e., not only one who presents himself as faithful) on the path to developing his personal spirituality and brings him the most convincing witness of God's love for man. Pope Francis appeals to unceasing missionary

19 Cf. Katechismus katolické církve, vyd. 2., Kostelní Vydří: Karmelitánské nakladatelství, 2002, pp. 50-67.

20 BENEDIKT XVI., Deus caritas est, Praha: Paulínky, 2006, art. 18. Further only DCE and section number.

21 Cf. DCE art. 17.

22 GS art. 1.

23 Cf. Walter FÜRST et al., „Selbst die Senioren sind nicht mebr die alten... “, p. 83. Based on an extensive qualitative study with older adults, Fürst and his colleagues identified meeting particular persons (and demanding life moments) as the greatest impulses setting off changes in the sphere of religiosity. 
activity with respect to its variability: "all of us are asked to obey his call to go forth from our own comfort zone in order to reach all the "peripheries" in need of the light of the Gospel". ${ }^{24}$

In a certain sense we could regard the rooms of homes for the elderly as such "periphery", whose inhabitants are not traditionally religious Christians and do not expressly ask for the Eucharist or other sacraments, or Christians who do not live in contact with the Church and practice their religiosity in the confines of their apartment and in their interior, or even, though religiously socialized, have partially or entirely lost their faith. If the spiritual shepherd systematically focuses only on the small group of his stable and proven "sheep", one can hardly speak of missionary impulse $e^{25}$ or open-door church. ${ }^{26}$

Openness consists also in emptying oneself of the concealed or admitted goal of pastoral care - e.g. conversion or return "to the bosom of the Church" ${ }^{27}$ On the other hand, while pastoral care may certainly not be confused with goal-oriented catechesis, the pastoral worker should not strive for some sort of "religious neutrality" either. For his inner strength stems not only from his personality qualities, but especially from his own Christian identity. In this sense Aleš Opatrný points out the essence of pastoral care, which "consists not only of talk of God, faith, or sacraments, and it is also not only a generally human talk, in which we avoid all mention of God." 28

We can summarize that the need for fulfilment in the sphere of spiritual needs is common to all elderly persons independently of their (non-)declared religious creed or denomination. The pastoral worker must be physically, mentally as well as spiritually present for all elderly persons in the spirit of Jesus Christ, especially for the "ill" ones (Mt 9:12-13), i.e., not for the constant group of devoted "church" faithful.

\section{Active listening}

The pastoral worker should become acquainted with the life story of the particular person, in order to be able to understand his attitude to faith, to religiosity, to participation in Church ceremonies. It is not a matter of some deep analysis of the history of his life, rather a willingness to give the elderly person time and space to express his own life story. Even the Vatican II document on mission, whose eleventh article bears the succinct title "Be and converse with people", ${ }^{29}$ in a certain sense points to active listening as the point of departure of any Christian intervention.

In conversation with an old person, whose strong need is to share his life story, Ecclesiastes's "it is time to be silent and time to speak" (Eccl 3:7) is especially valid. Active listening helps to discover the real causes of long nurtured and verbally declared negative religious (and non-religious) attitudes, as well as contradictions in the consistency of extrinsic and intrinsic

24 FRANTIŠEK, Evangelii gaudium. Radost evangelia: apoštolská exbortace o blásání evangelia v současném světě, Praha: Paulínky, 2014, art. 20.

25 Ibid, art. 48

26 Ibid, art. 46.

27 Cf. Aleš OPATRNÝ, Malá př́ručka pastorační péče o nemocné, Praha: Pastorační středisko Arcibiskupství pražského, 2003 , p. 8.

28 Ibid.

29 Dokumenty II. vatikánskébo koncilu, Praha: ZVON, Ad gentes, art. 11. 
living out of Christian spirituality, viz. deficiencies in basic principles of Christian spirituality, as defined e.g. by J. P. Ondok. ${ }^{30}$ The pastoral worker is thus an indispensable guide on the path to salvation, since, as Gaudium et spes states, "the split between the faith which many profess and their daily lives deserves to be counted among the more serious errors of our age." 31 The elderly person may have been living in such split for many decades, without being aware of it and without someone talking to him about it.

Active listening also enables the pastoral worker to discover the language which the older person speaks with respect to religiosity. "Unbelief", "atheism", or on the other hand "faith" may be understood in many ways, which it is impossible to figure out without knowing the person's history and the story of his faith. In this sense A. Opatrný32 points out the need for caution in dividing people into "faithful" and "non-faithful". "Non-faithful" can be people who already really do not accept faith in God, but they can also be people who have a negative attitude to the Catholic Church, or to church in general, or to any form of religion, but they do "count" with God in some way. Thus declared variability of "non-faith" has been confirmed by the conclusions of the research study Spiritual Needs in the Life of Elderly Persons in South Bobemia, based on which we may add one other possible attitude of those who present themselves as "non-faithful". They may be persons who would like to "count" with God and feel his presence in their life, but have not been able to establish this relationship due to injuries, misunderstandings or ignorance. The reasons for their attitude are frequently almost unexpressed, or expressed "between the lines", and careful and patient listening is thus the only way to grasp these nuances properly and evaluate them with respect to further pastoral procedure.

We can summarize that active listening opens the door to the elderly person's soul and fulfils many of his spiritual needs. By active listening conducted in respect and love it is possible to detect some injuries of spiritual or even religious character, which prevent the older person from opening up to a relationship with God, but also some dogmatic errors originating in superficial childhood catechesis without further religious guidance (literally tragic is the impact of erroneous ideas and prejudices concerning the sacrament of reconciliation).

\section{Respect to the personal story of religious or spiritual development}

An essential aspect of meaningful pastoral care is respect to the given person's level of faith. ${ }^{33}$ In old age this recommendation receives a further dimension. Elderly persons have already lived through the greater part of their life and have reached the present form of their faith by way of many life experiences, demanding life moments or decisions. P. Ambros points out that "the person's life story and the history of his faith are a single, indivisible reality". ${ }^{34}$ Divine guidance and divine presence thus manifests itself in mundane everyday events, as well as in decisive moments and life crises. Although elderly persons are still the most

30 Cf. Josef Petr ONDOK, Čmelák asketický: Úvaby o křestáanské spiritualitě, Svitavy: Trinitas, 2003, p. 45.

31 GS art. 43.

32 Cf. Aleš OPATRNÝ, Pastorace zvláštních skupin, p. 21.

33 Cf. Aleš OPATRNÝ, Malá príručka pastorační péče o nemocné, p. 9.

34 Cf. Pavel AMBROS, Fundamentální pastorální teologie, p. 117. 
religious group in the population (in the sense of traditional religiosity), it is not possible to assume some level of spiritual maturity due to age. The way older persons live out religiosity or spirituality is individual precisely because it reflects their life story.

Understanding the life story of the particular person as an essential part of the story of his faith is thus one of the necessary aspects of meaningful spiritual accompanying. The results of the study Spiritual Needs in the Life of Elderly Persons in South Bobemia have also discovered marked variability in the form of the religiosity of older Christians (i.e., those who have been baptized): for most of them God was "somehow present" in their life, but none of them had maintained continual religious practice throughout life.

\section{Discovering and reinforcing own spiritual resources}

The image of ill, dependent and lonely old age in combination with great willingness to serve the neighbour can conceal the great potential of the old person for the pastoral worker: his inner strength, resilience, experience, strategies, strong personal relationship to God, ability to seek and see connections and meaning of own life story, ability to sacrifice his affliction for others. This potential can often be concealed and unadmitted and suitably conducted pastoral care can support its development.

The accompanying person should help the older person make full use of the wealth which consists in the spiritual sphere of his life. Spiritual intervention should aim especially at strengthening and developing strong character aspects, abilities and skills, at reinforcing positive attitudes and values, at confirming consciousness of dignity and self-confidence e.g. by means of the ability to be grateful. Fišer states a practical example of daily meditation aimed at reinforcing own resources through experiencing gratitude: "Think rather of such things and thank God and people for them. Begin with today: What have the others done for you? Who took care of you? Who cooked for you? Who tidied up? Who visited you? Who looked at you kindly? Thank each one of them in your heart. And thank God for all and everything! Now proceed to the past and in prayer thank all your closest ones. (...) Remember everything each one of them did for you in the course of your last illness, during the war and after it, in the years of totality, in other hard times - here where you live, elsewhere while travelling. Return in thought to your childhood and youth. (...) Thank God for having always forgiven you (...) do not return to sins that have been forgiven long ago." ${ }^{35}$ Gratitude intensifies trust in God's plan with man, in his love for man, as well as selfconfidence, faith in a higher meaning of life and higher reality of which I am part. It is thus a precondition to overcoming not only actual doubts concerning oneself, but even basal distrust arisen in childhood. ${ }^{36}$

The meaning of pastoral care is not to make the older person dependent on spiritual accompanying (or the person of the pastoral worker), but to help him arouse and reinforce his own strength and spiritual resources for reconciliation with his life, with people, with

35 Zdeněk Cyril FIŠER, Plný život ve stâř́, Kostelní Vydř́: Karmelitánské nakladatelství, 2001, p. 34.

36 On the relationship of basal trust or distrust and the image of God see more Karl FRIELINGSDORF, Falešnépredstavy o Bobu, Kostelní Vydř́: Karmelitánské nakladatelství, 2010, p. 173 and elsewhere. 
God, to meaningfully cope with his own story, to find or maintain hope and faith, to realize his own dignity independent of external circumstances or knowledge, achievement or merits. Then he can also fulfil the task issuing from the essence of old age and relating to his inner world, but also outward - to the people around him, to the younger generation, to God..$^{37}$

\section{Conclusion}

Although quality social care should comprise the human being in his bio-psycho-sociospiritual unity, in the practice of homes for the elderly the spiritual dimension of life is left aside. Pastoral care ought not to be some other "social service for the needy", but a natural part of life in the given establishment. Older people long for contact, need to mirror their feelings, concerns, joys, share their life knowledge and experience, they need to talk of their family and relationship to God, they need to feel real interest in their person, love and support: "Then the Lord God said, "It is not good that the man should be alone" (Gn 2:18). Metaphorically speaking, their soul is hungry. Pastoral care mostly cannot banish difficulties from the life of an older person, but it can help him cope with these difficulties in a dignified way and meaningfully integrate them in his own life story. Strong spiritual anchoring contributes to consciousness of own dignity, is an important source of some sort of inner refuge independent of external circumstances, and is thus a filter through which one judges oneself.

The pastoral worker should be aware of the specificities of old age in physical, psychological, social and spiritual sphere; only in that way can he be a truly accompanying partner to the old person, only in that way can he fulfil the pastoral event, not only the letter. ${ }^{38} \mathrm{An}$ insensitive intervention, though bolstered by theological knowledge and well-meant, can for a long time close the imaginary door to the heart of the older person and confirm him in the decision to remain in the security of a private "religious hideaway", where there is not much space for spiritual growth - which is in direct contradiction to the meaning of pastoral care. Love, respect and acknowledgement of the uniqueness of the life story of the particular person, on the other hand, opens the path to spiritual growth and possibly shared "spiritual work". Meaningful care of the spiritual development of a human being is thus contingent on personal equipment and good will as well as adequate education - formal, informal or experiential.

A humanly and spiritually mature pastoral worker, aware of the specificities of old age, can mediate contact with the real gospel to the older person and reinforce him in the sphere of spiritual needs - otherwise he will step in the multitude of many others who communicate with the old person without really seeing and hearing him, even though this worker brings the Eucharist to the home for the elderly, "leads the singing", or celebrates mass.

37 As all church documents mentioned in this paper emphasize, an old person is not (and should not be) some sort of a "helpless" pastoral object, but has great potential to be the subject of pastoral care especially among his peers.

38 Cf. Pavel AMBROS, Dvojí tvář pastorace. Litera a duch, in: Pronikavá żmèna pastorace nebo sebezáchovný provoz? Být církví misionáršsým zpuisobem: mezinárodní pastorálně teologické sympozium, eds. Zdeněk DEMEL - Karl SCHLEMMER, České Budějovice: Teologická fakulta Jihočeské univerzity, 2005, p. 115. 


\title{
Pastoral Care in Homes for the Elderly: Selected Issues
}

\begin{abstract}
Pastoral care of the elderly in the sense of accompanying an older person in the story of life and faith requires a functional relationship between the pastoral worker and the recipient of pastoral care. The paper first brings a brief reflection of the contemporary practice of pastoral care in homes for the elderly in CR as a specific pastoral environment, then, based on the conclusions of the qualitative study Spiritual Needs in the Life of Elderly Persons in South Bohemia, defines and characterizes aspects of meaningful pastoral care (not only) in this specific pastoral milieu: own initiative of the pastoral worker in establishing contact with the elderly persons, point of departure in love of the neighbour, openness to all elderly persons regardless of their declared creed, ability to actively listen to their life story, respect for the personal story of religious or spiritual development of the particular person and assistance in discovering and reinforcing his own spiritual resources.
\end{abstract}

Keywords: old age, home for the elderly, pastoral work, pastoral worker, spiritual needs

\section{Contact}

Dr. Vèra Suchomelová

University of Souht Bohemia, České Budějovice

Faculty of Theology, Department of Education

Kněžská 8, 37001 České Budějovice

suchomelova@seznam.cz 